\title{
Portraits of two innovative plastic surgeons in the National Portrait Gallery
}

\author{
Kun Hwang \\ Department of Plastic Surgery, Inha University School of Medicine, Incheon 22332, South Korea.
}

Correspondence to: Dr. Kun Hwang, Department of Plastic Surgery, Inha University School of Medicine, 27 Inhang-ro, Jung-gu, Incheon 22332, South Korea. E-mail: jokerhg@inha.ac.kr

How to cite this article: Hwang K. Portraits of two innovative plastic surgeons in the National Portrait Gallery. Plast Aesthet Res 2017;4:15-7.

Article history: Received: 29-12-2016 Accepted: 09-01-2017 Published: 22-02-2017

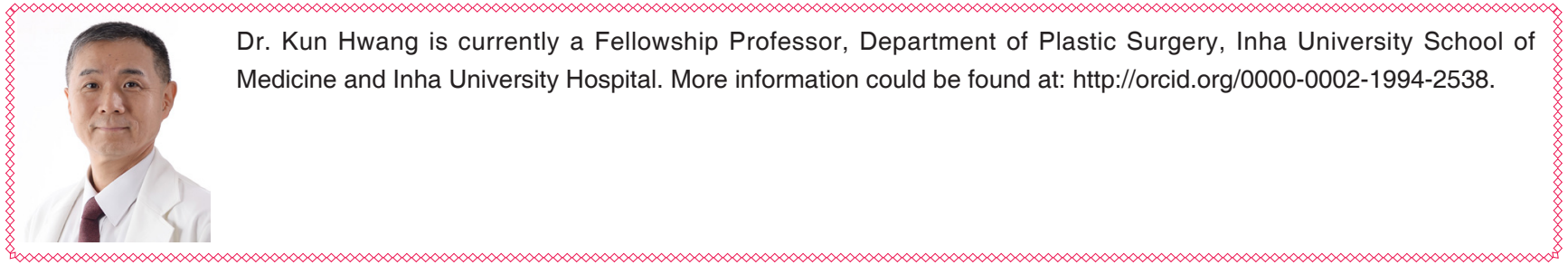

It must at all times be kept in mind that the most important person is first, last, and all the time the patient. $^{[1]}$ - Archibald Mclndoe

As a medical doctor, when I visit a gallery or museum, I look for portraits of medical doctors. During my stay in London, I visited the National Portrait Gallery, where I happened to see the portraits of two famous plastic surgeons: Sir Harold Delf Gillies (1882-1960, Figure 1) and Sir Archibald Hector Mclndoe (19001960, Figure 2). The name "Gillies" caught my eye because the approach named after him is one of the indirect approaches for the reduction of the zygomatic arch (Gillies: temporal; Keen: transoral; and Dingman: lateral brow). The name "Mclndoe" was also familiar because of the "Mclndoe operation" for reconstruction of the vagina in the congenital absence of the vagina, using an indwelling skin graft. ${ }^{[2]}$
World War I (WWI, 1914-1918) was characterized by trench warfare, during which Combatant's head and neck were exposed to high-energy weapons, resulting in severe facial wounds. ${ }^{[3]}$

Gillies was born in New Zealand and studied medicine at Cambridge University. When WWI began, he joined the Royal Army Medical Corps.

While working in France, Gilllies met French-American dentist, Charles Valadier, and learned the basics of repairing jaw injuries, including how to do bone grafting. After his return to England, he worked at the Queen's Hospital, which was devoted to facial repairs. He developed many plastic surgery techniques. From 1917 to 1925 , he performed more than 11,000 operations for 5,000 soldiers with facial injuries. ${ }^{[4]}$ His pre- and postoperative results were drawn by artist 


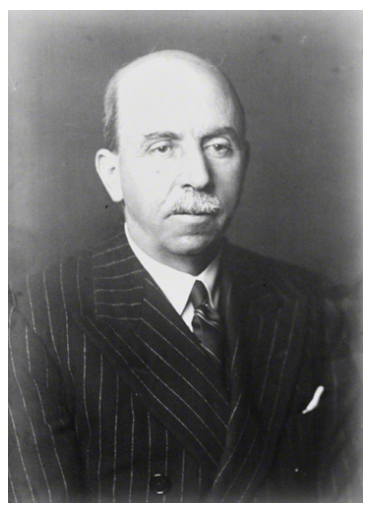

Figure 1: Sir Harold Delf Gillies (1882-1960), Plastic Surgeon
Henry Tonks with pastels, and by Daryl Lindsay with watercolors.

Mclndoe was born in New Zealand and studied medicine at the University of Ontago and moved to London at the age of thirty. When Mclndoe arrived in United Kingdom, his cousin Gillies got Mclndoe a temporary position at St Bartholomew's Hospital in London. Mclndoe worked here for less than a year and obtained his British qualifications. Gillies put Mclndoe forward for a lecturer position at the Hospital for Tropical Diseases. Mclndoe was successful but he soon became bored of this position, so Gillies invited him to join his private practice. From 1931 to 1939 , they performed hundreds of operations together and devised new techniques.

In World War II (1939-1945), the survival rates from the combat wounds increased due to the development of blood transfusion, endotracheal intubation, and rapid evacuation by aircraft. ${ }^{[5]}$ Severe burn cases appeared due to massive air strike from bombers. Thereafter, burn care significantly advanced during World War II.

Following the outbreak of World War II, Mclndoe moved to the newly built Queen's Hospital and treated deep burn injuries and serious facial deformities, like the loss of eyelids.

At that time, the standard treatment for burns was coagulation with tannic acid, which is very painful. He observed different healing rates in extensively burned pilots who had come down on land and in the sea. From this, he discovered that immersion in saline promoted healing as well as improving survival rates, and thus began saline baths and early grafting instead of tannic acid. He recognized the importance of rehabilitation and social reintegration back into normal life. ${ }^{[1]}$ In fact, over eighty percent of his aircrew patients returned to duty. ${ }^{[6]}$

On arriving home from the museum, I searched for the number of papers they wrote and their titles. Gillies and

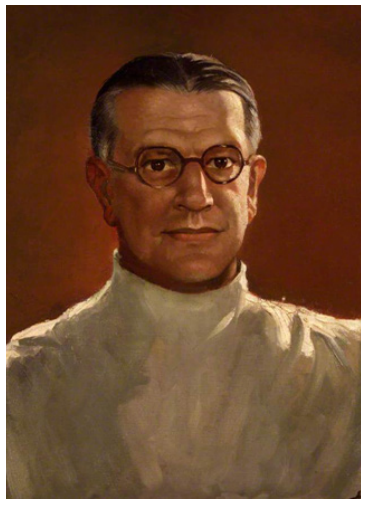

Figure 2: Sir Archibald Hector Mclndoe (1900-1960), Plastic Surgeon
Mclndoe published 12 and 17 papers, respectively. Among them were 2 articles they co-authored. ${ }^{[7,8]}$

Gillies wrote "A new principle in the surgical treatment of "congenital cleft palate" and its mechanical counterpart" (1921, cited 113 times) ${ }^{[9]}$ and "The design of direct pedicle flaps" (1932, cited 29 times), ${ }^{[10]}$ among others.

His technique for the treatment of cleft of hard and soft palate was based on a combined surgical and dental treatment. Soft palate was paired and lengthened surgically by separating the soft palate from the hard palate. A dental apparatus was applied on the hard palate, and skin graft was applied to the raw anterior edge of palate. After healing, Fry's apparatus was applied for stretching the soft palate. ${ }^{[9]}$

Mclndoe developed many new techniques, reflected in his publications which included "Total reconstruction of the burned face. The Bradshaw Lecture" (1958, cited 41 times), ${ }^{[11]}$ "Symposium: radiation necrosis" (1947, cited 32 times), ${ }^{[12]}$ "Operation for the cure of adult hypospadias" (1937, cited 23 times), ${ }^{[13]}$ "Surgical and dental treatment of fractures of the upper and lower jaws in war time" (1941, cited 15 times), ${ }^{[14]}$ "The burned hand" (1945, cited 12 times),, ${ }^{[15]}$ and "Congenital absence of the vagina, treated by means of an indwelling skin-graft" (1938, cited 9 times). ${ }^{[2]}$

His methods were very innovative and the first successful reconstruction for congenital absence of the vagina. A hollow vulcanite mold was used, which was completely closed at both ends, with the size and shape of a distended virgin vagina. A split thickness skin graft ( 9.5 inch long by 2.5 inch wide) was harvested from the inner thigh. An incision was made from a point half an inch posterior to the urethral meatus and carried vertically backwards to a point $3 / 4$ inch in front of the anus. Blunt dissection was carried between the rectum and the bladder and a cavity was made for the mold. The mold was covered with the 
Table 1: Brief summary of Dr. Gillies and Dr. Mclndoe

\begin{tabular}{|c|c|c|}
\hline & Gillies (1882-1960) & Mclndoe (1900-1960) \\
\hline Born & New Zealand & New Zealand \\
\hline Medical School & Cambridge University & University of Ontago \\
\hline Active in & WW I & WW II \\
\hline Worked in & Queen's Hospital & Queen's Hospital \\
\hline Operated mostly & Gunshot facial injury & Burns \\
\hline Articles (co-work) & $12(2)$ & $17(2)$ \\
\hline Cited (co-work) & $162(14)$ & $127(14)$ \\
\hline Most cited papers & $\begin{array}{c}\text { Congenital cleft palate } \\
(113), \\
\text { Direct pedicle flap (29) }\end{array}$ & $\begin{array}{c}\text { Reconstruction of burned } \\
\text { face (41), } \\
\text { Radiation necrosis (32), } \\
\text { Operation for adult } \\
\text { hypospadia (23), } \\
\text { Treatment of fracture of } \\
\text { jaw (15), } \\
\text { Congenital absence of } \\
\text { vagina by indwelling skin } \\
\text { graft (9) }\end{array}$ \\
\hline
\end{tabular}

skin graft, raw surface outwards. The skin-covered mold was inserted into the cavity and the labia minora were sutured across its lower end leaving a small hole anteriorly just behind the meatus for drainage. The skin-covered mold was maintained for 5 months after operation. ${ }^{[1]}$

It goes without saying that these two New Zealand born cousins were innovative plastic surgeons [Table 1]. Where did their innovative thinking come from? As in Gillies' case, innovation can come from being informed by other subjects of study or specialties. Innovation comes also from close observation, as in Mclndoe's case. However, innovation mostly arises out of necessity, as when Gillies and Mclndoe pursued their field practice.

\section{Financial support and sponsorship}

This study was supported by Inha University (INHAResearch Grant).

\section{Conflicts of interest}

There are no conflicts of interest.

\section{Patient consent}

Not applicable.

\section{Ethics approval}

Not applicable.

\section{REFERENCES}

1. McIndoe AH. Surgical responsibility in relation to injury. $J R$ Inst Public Health 1946;9:335-42.

2. Banister JB, McIndoe AH. Congenital absence of the vagina, treated by means of an indwelling skin-graft. Proc R Soc Med 1938;31:1055-6.

3. Backstein R, Hinek A. War and medicine: the origins of plastic surgery. Univ Toronto Med J 2005;82:217-9.

4. Wikipedia. Harold Gillies. Available from: https://en.wikipedia.org/ wiki/Harold_Gillies. [cited 2017 Jan 3]

5. Chambers JA, Ray PD. Achieving growth and excellence in medicine: the case history of armed conflict and modern reconstructive surgery. Ann Plast Surg 2009;63:473-8.

6. Wikipedia. Archibald McIndoe. Available from: https://en.wikipedia. org/wiki/Archibald_McIndoe. [cited 2017 Jan 3]

7. Gillies HD, McIndoe AH. The role of plastic surgery in burns due to Roentgen rays and radium. Ann Surg 1935;101:979-96.

8. Gillies H, McIndoe AH. The late surgical complications of fracture of the mandible. Br Med J 1933;2:1060-3.

9. Gillies HD, Fry WK. A new principle in the surgical treatment of "congenital cleft palate" and its mechanical counterpart. $\mathrm{Br}$ Med $J$ 1921;1:335-8.

10. Gillies HD. The design of direct pedicle flaps. Br Med J 1932;2:1008.

11. McIndoe AH. Total reconstruction of the burned face. The Bradshaw Lecture 1958. Br J Plast Surg 1983;36:410-20.

12. McIndoe AH, Forbes R, Windeyer BW. Symposium: radiation necrosis. Br J Radiol 1947;20:269-78.

13. McIndoe AH. Operation for the cure of adult hypospadias. Br Med J 1937;1:385-404.

14. McIndoe AH. Surgical and dental treatment of fractures of the upper and lower jaws in war time a review of 119 cases: (section of odontology). Proc R Soc Med 1941;34:267-88.

15. McIndoe AH. The burned hand. Mod Treat Yearb 1945:221-31. 